\title{
Tectonic control over drainage basin of South Andaman Island: study toward hydro-morphometric analysis
}

\author{
Swati Ghosh ${ }^{1,3} \cdot$ Ashis Kr. Paul ${ }^{2}$
}

Received: 27 May 2019 / Accepted: 1 October 2019 / Published online: 11 November 2019

(c) The Author(s) 2019

\begin{abstract}
Scientists and researchers in ancient and modern times have profoundly applied morphometric analysis to evaluate quantitative description of landforms or drainage basins and large regions. The objective of this study is to enlighten certain features like tectonic control over drainage basin, the hydro-geomorphic characteristics of the drainage system and the geomorphic maturity of terrain of South Andaman Island. After extensive studies, drainage system in this particular island is broadly classified into five major drainage patterns (dendritic, trellis, parallel, radial and centripetal). An attempt has been made here to investigate the in-depth morphometric characteristics of dendritic pattern of a fourth-order watershed. In earlier attempts, researchers have used morphometric analysis to calculate stream ordering, stream length, length ratio and bifurcation ratio as part of linear aspects and drainage density, stream frequency, form factor, circulatory ratio, elongated ratio as part of areal aspects. The present case study has been carried out in remote sensing and geographical information system (GIS) environment. Shuttle Radar Topographic Mission data has been used to prepare the digital elevation model and GIS to evaluate all linear, areal and relief aspects of this small drainage basin in South Andaman Island which was never unearthed till date.
\end{abstract}

Keywords Terrain $\cdot$ Morphometry $\cdot$ SRTM $\cdot$ DEM $\cdot$ GIS

\section{Introduction}

The fundamental of this research paper is based on morphometric analysis of a small drainage basin in South Andaman Island, India. Morphometry as defined by Agarwal (1998) is a useful technique to quantify and analyze mathematically the earth's surface configuration and the shapes and dimensions of its landforms. In the recent past, emphasis was given to the development of quantitative methods to assess the behavior and evolution of the surface drainage networks (Horton 1945; Leopold and Maddock Jr 1953; Abrahams 1984). Studies had already established the major factors like climate, relief and geology in

Swati Ghosh

sgswatighosh@gmail.com

1 Department of Geography, University of Calcutta, Kolkata, India

2 Department of Geography and Environment Management, Vidyasagar University, Midnapore, India

3 Kolkata, India determining the activities of the running water ecosystem at basin scale (Lotspeich and Platts 1982; Frissel et al. 1986). Morphometric parameters have been profoundly applied to describe basin forms and processes. These parameters assist to compare various basin characteristics (Mesa 2006) and help to understand the geological and geomorphic history of the basin area (Strahler 1964). Horton (1945) was one of the greatest researchers to invent quantitative analysis of drainage basins which was later modified by Strahler in traditional means. The conventional methods are now been replaced by GIS and satellite remote sensing (Biswas et al. 1999; Nageswara Rao et al. 2010; Krishnamurthy and Srinivas 1995: Srivastava and Mitra 1995: Agarwal 1998) to record the same. Morphometric analysis was employed for characterizing watersheds (Nag 1998; Vittala et al. 2004), flood potentiality of drainage basins, evaluation of prevailing geohydrological characteristics, watershed planning and management (Hajam et al. 2013). It describes the influence of lithology in the drainage development (Pareta and Pareta 2011), drainage morphometry on hydrology. This case study is designed to describe the nature of spatial variations, physical characteristics and

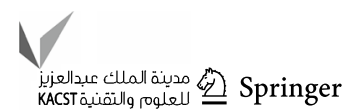


the impact of tectonics over the drainage basin. Among the widely used techniques as described, GIS methodologies have been implemented to accomplish the morphometric analysis of the South Andaman drainage basin. This tool is devised to provide a powerful and flexible environment for the manipulation and analysis of spatial information.

\section{Study area}

The investigated area is located in the new Rangachang village of Port Blair tehsil of South Andaman Island (Fig. 1). The area of the concerned dendritic basin is $18.51 \mathrm{~km}^{2}$ and is situated between $11^{\circ} 32^{\prime} \mathrm{N}$ to $11^{\circ} 35^{\prime} \mathrm{N}$ latitude and $92^{\circ}$ $41^{\prime} 30^{\prime \prime} \mathrm{E}$ to $92^{\circ} 44^{\prime} \mathrm{E}$ longitude (Fig. 1e). The main channel originates at an altitude of 160 meters. Initially, it takes a southeasterly course, then flows into northeasterly direction and ultimately debouches into the Andaman Sea. There are numerous small tributaries that pour into the channel. As per the analysis, it is found that a fourth-order watershed is formed in this region. These channels are said to be rain fed. The average annual rainfall of the island varies from 3000 to $3500 \mathrm{~mm}$.

\section{Tectonic setting and geology of South Andaman Islands}

The tectonic history and geology of the Andaman Island and its surrounding region are very complex due to the presence of tectonic features and active faults such as West Andaman Fault in Andaman Sea and Diligent Fault. Andaman Nicobar Ridge is an accretionary prism of Sunda subduction zone. The basic structure of the ridge is an imbricate stack of eastward dipping fault slices and folds.

According to Oldham, the stratigraphy of the Andaman Island falls into two basic formations, the Port Blair series and the Archipelago series. The Port Blair series mainly consists of firm gray sandstone and imbedded gray shale with minor amounts of coaly matter, conglomerate and limestone. The sandstone is the characteristic rock of this series. The younger Archipelago series consist typically of soft limestone which is formed from coral, shell, sand, soft calcareous sandstones and soft white clays. Later on, the Port Blair Formation was known as Andaman Flysch. The present study area coincides with the Andaman Flysch sediment and composed of Eocene sandstones (Fig. 2B). Some serpentines are also found in the uppermost part of the drainage basin. According to various authors, this Andaman Flysch or Port Blair Formation sandstones are turbidities and they were interpreted as sediments of the Bengal
Fan (Curray et al. 1979). The underlying rock of the basin is acid plutonic.

\section{Materials and methods}

The dendritic pattern was first identified and delineated from SOI topographic maps of 1979 with no. $87^{\mathrm{A} / 10}$ on the scale 1:50,000. The exact basin area was demarcated and extracted from the Aster DEM of 30-meter resolution. For an authentic morphometric analysis, sinks were removed from Aster data. Finally, the standard flow paths were generated over the DEM using watershed analysis. The sub-basins were computed by changing the value of the basin parameter. Along with the flow paths and standard basins, all other watershed attributes were also generated. The drainage channels were characterized according to their corresponding drainage order. The entire task was carried out in remote sensing and GIS environment by using TNT MIPs software. The morphometric parameters were divided into three categories: linear, areal and relief aspects. The basic parameters like basin area, perimeter, length and stream length were extracted from the geo-database, and other parameters were derived from these basic parameters by means of various mathematical equations (Table 1).

\section{Results and discussions}

\section{Linear aspects}

\section{Perimeter $(P)$}

The perimeter of the studied basin was calculated to be $18.51 \mathrm{~km}$ (Table 2). Basin ID 19 was recorded to have the minimum value of $1.3 \mathrm{~km}$, whereas Basin ID 14 has the maximum value of $7.6 \mathrm{~km}$ among all the sub-basins (Table 5).

\section{Basin length $\left(L_{b}\right)$}

The length of the basin of fourth-order watershed is $5.2 \mathrm{~km}$ (Table 2). In case of sub-basins (Table 5), it ranges from $0.28 \mathrm{~km}$ (Basin ID 19) to $3.58 \mathrm{~km}$ (Basin ID 14). Basin ID 14 is relatively elongated and it covers the maximum area $\left(1.5 \mathrm{~km}^{2}\right)$. Hence, in this case, headward erosion plays the key role in making the channels lengthy and forms an elongated basin.

\section{Stream order $\left(\mathrm{S}_{u}\right)$}

Strahler method has been followed in this current case study to determine the stream ordering (Fig. 3). There are a total 


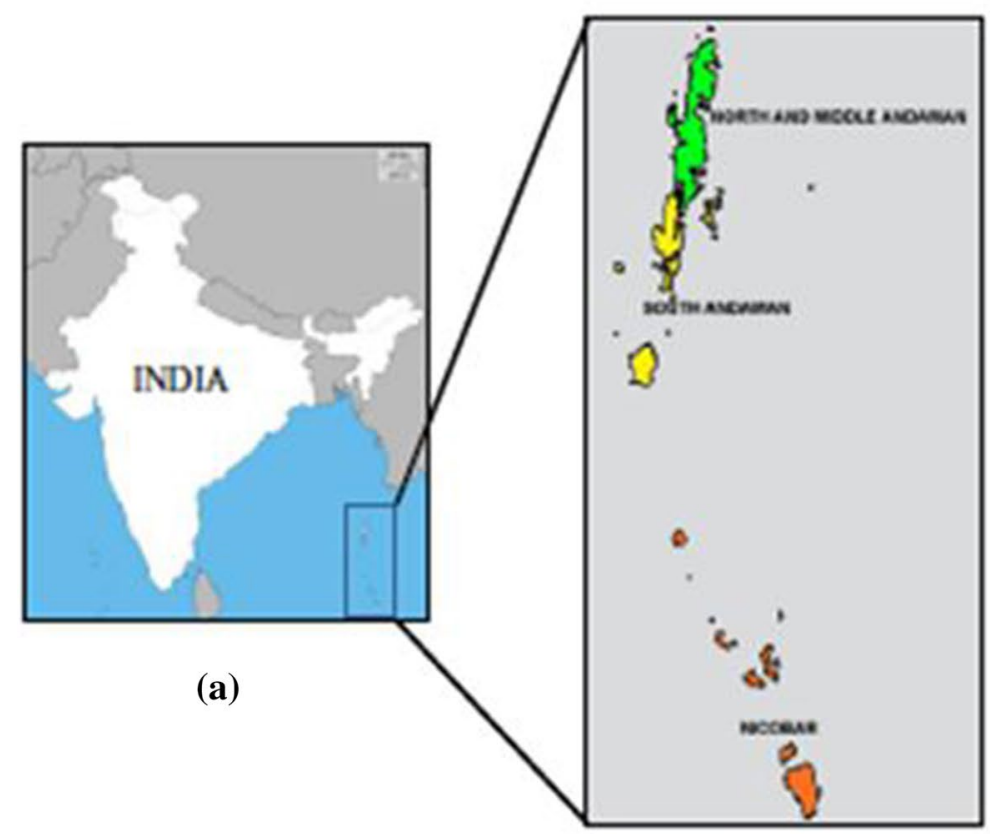

(b)

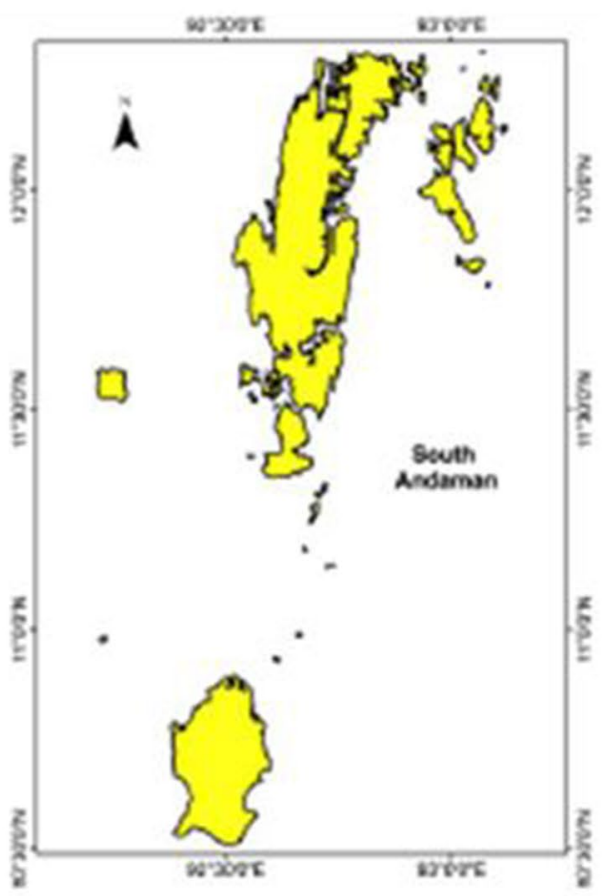

(c)

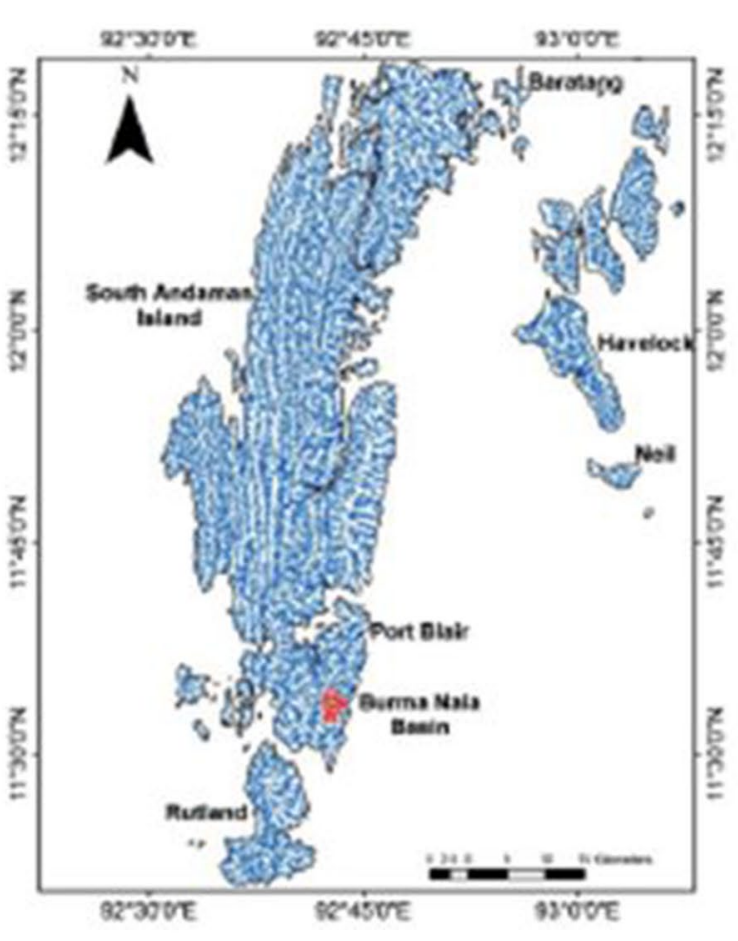

(d)

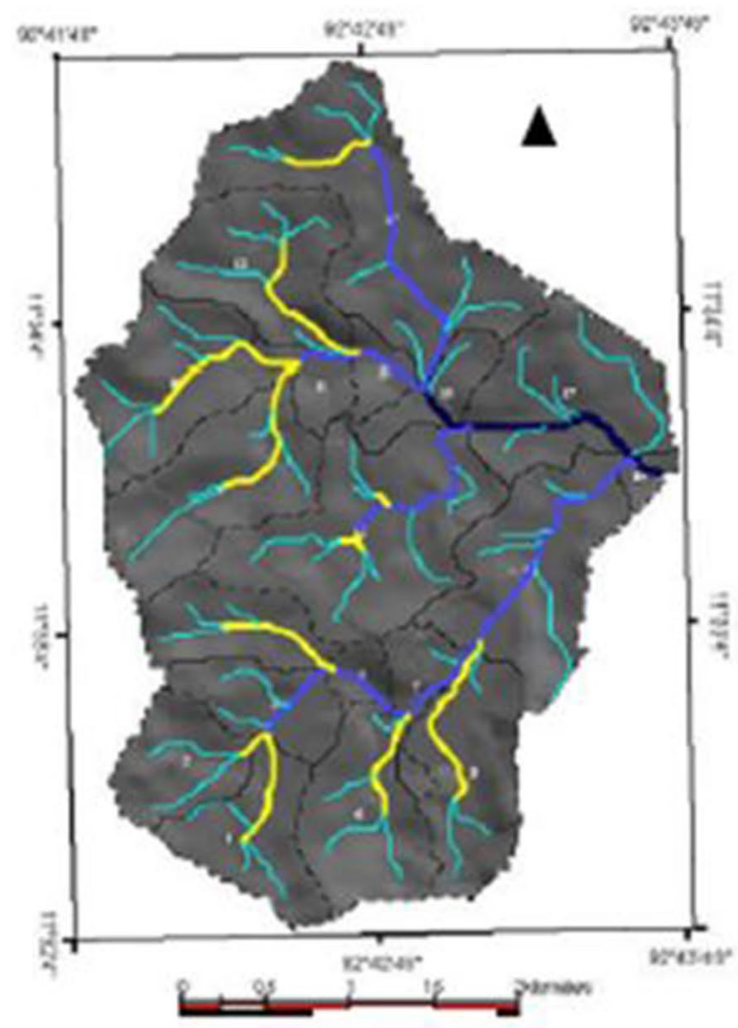

(e)

Fig. 1 Location map: a India, b Andaman Nicobar Island, c South Andaman Division, d drainage map of South Andaman Island, e fourth-order dendritic drainage basin 


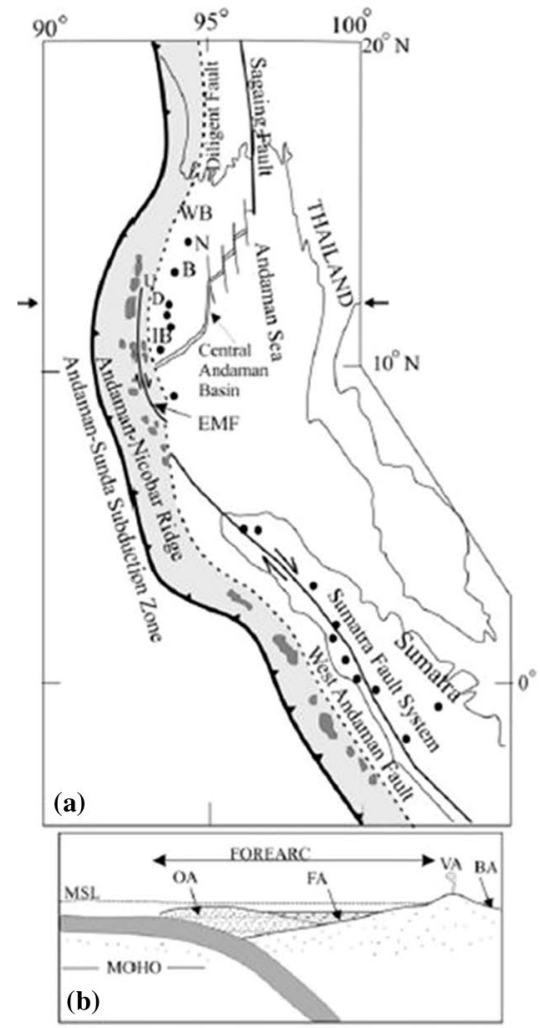

A
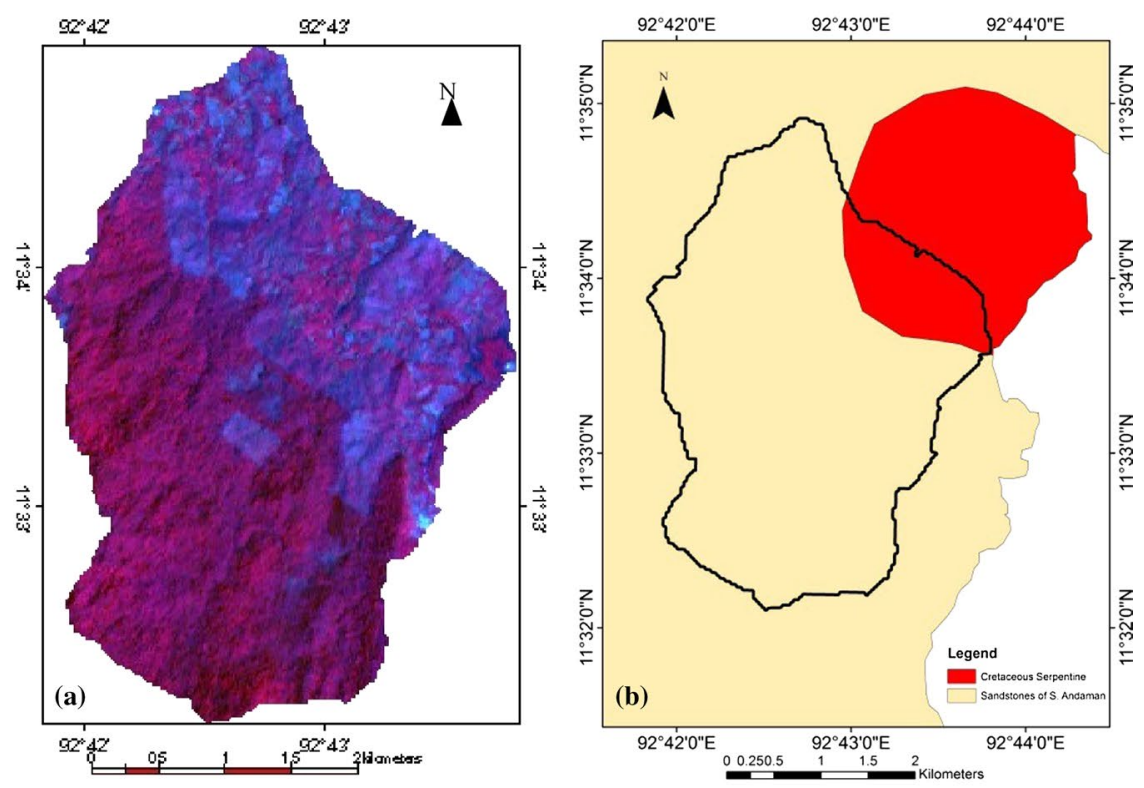

B

Fig. 2 A Map showing major tectonic units of A \& N region. B (a) Satellite image (Landsat ETM+2000) of the watershed, (b) geological map of the watershed and surrounding area (source: Geological Survey of India)

of 74 channels linked to form the fourth-order watershed. It is found that the maximum frequency is in the case of firstorder streams (77.02\%, maximum proportion) and with the increasing order, the frequency decreased. Thus, the law, the lower the order, the higher the frequency and vice versa, is implied throughout the basin.

\section{Total stream length $\left(L_{u}\right)$}

The stream length of various orders has been calculated. It is found that the total stream length decreases with the increasing order (Table 2). It is observed that first-order stream constitutes $58.62 \%$ of the total stream length, secondorder stream constitutes $19.04 \%$ and third-order stream has $18.14 \%$ and fourth order has $4.19 \%$.

\section{Mean stream length $\left(L_{u m}\right)$}

In this study, it is found that the mean length increases with increasing order (Table 2), but an exception has been observed in the fourth order. Here, the mean stream length is lower than that of lower order.

\section{Stream length ratio $\left(R_{l}\right)$}

In Table 2 , the $R_{1}$ is found to vary arbitrarily, that is, 0.32 , 0.95 and 0.23 which indicates the late youth to early maturity stage of geometric development.

\section{Bifurcation ratio $\left(R_{\mathrm{b}}\right)$}

Theoretically, when the value ranges from 3 to 5 , it seems geologic structure does not distort the drainage pattern (Strahler 1964). In the concerned study area, the $R_{\mathrm{b}}$ values vary from 3 to 4.75 (Table 2 ) with a mean bifurcation ratio of 3.92. The relatively higher value of bifurcation ratio is an indication of structural disturbances and high overland flow due to the presence of hilly, less permeable underlying rocks.

\section{Areal aspects}

\section{Area (a)}

The area of the fourth-order watershed is $11.73 \mathrm{~km}^{2}$ (Table 4). Among all the 19 sub-basins, the area of Basin 11 is lowest $\left(A=0.2 \mathrm{~km}^{2}\right)$ and Basin 14 is recorded to be the largest $\left(A=1.5 \mathrm{~km}^{2}\right)$ (Table 5). 
Table 1 Morphometric parameters used for the morphometry analysis

\begin{tabular}{|c|c|c|c|}
\hline $\begin{array}{l}\text { Sl. no. mor- } \\
\text { phometric } \\
\text { parameter }\end{array}$ & Formula & & References \\
\hline 1. & Perimeter $(P)$ & Length of the watershed boundary & \\
\hline 2. & Basin length $\left(\mathrm{L}_{b}\right)$ & Maximum length of the watershed & \\
\hline 3. & Stream order $\left(\mathrm{S}_{u}\right)$ & Hierarchical ordering & \\
\hline 4. & Total stream length $\left(L_{\mathrm{u}}\right)$ & Length of total streams & Strahler (1964) \\
\hline 5. & Mean stream length $\left(L_{\mathrm{um}}\right)$ & Average length of the stream & Strahler (1964) \\
\hline 6. & Stream number $(\mathrm{Nu})$ & & Horton (1945) \\
\hline 7. & Bifurcation ratio $\left(R_{\mathrm{b}}\right)$ & $\begin{array}{l}\mathrm{Nu} / N(u+1), \text { where } \mathrm{Nu} \text { is number of streams of } \\
\text { any given order and } N(u+1) \text { is number in the } \\
\text { next higher order }\end{array}$ & Horton (1945) \\
\hline 8. & Stream length ratio $\left(R_{1}\right)$ & $\begin{array}{l}L_{\mathrm{u}} / L(u-1), L_{\mathrm{u}} \text { is stream length of order } u \text { and } \\
L(u-1) \text { is stream segment length of the next } \\
\text { lower order }\end{array}$ & Horton (1945) \\
\hline 9. & Rho coefficient $(p) R_{\mathrm{l}} / R_{\mathrm{b}}$ & & Horton (1945) \\
\hline 10. & Weighted mean bifurcation ratio $\left(R_{\mathrm{bwm}}\right)$ & & Strahler (1953) \\
\hline 11. & Area $(A)$ & Area of the watershed & \\
\hline 12. & Drainage density $\left(D_{\mathrm{d}}\right)$ & $\begin{array}{l}\mathrm{Lu} / A \text {, where } \mathrm{Lu} \text { is total length of all ordered } \\
\text { stream }\end{array}$ & Horton (1945) \\
\hline 13. & Stream frequency $\left(F_{s}\right)$ & $\mathrm{Nu} / A, \mathrm{Nu}$ is total number of streams of all order & Horton (1945) \\
\hline 14. & Drainage texture $(T)$ & $\mathrm{Nu} / P$ & Horton (1945) \\
\hline 15. & Length of overland Flow $\left(L_{\mathrm{g}}\right)$ & $1 / 2 D_{\mathrm{d}}$ & Horton (1945) \\
\hline 16. & Constant of channel maintenance $(C)$ & $1 / D_{\mathrm{d}}$ & Schumm (1956) \\
\hline 17. & Form factor $\left(F_{\mathrm{f}}\right)$ & $A / L_{\mathrm{b}}^{2}$ & Horton (1945) \\
\hline 18. & Circularity ratio $\left(R_{\mathrm{c}}\right)$ & $4 * 3.14 A / P^{2}$ & Miller (1953) \\
\hline 19. & Elongation ratio $\left(R_{\mathrm{e}}\right)$ & $A * 1.128 / \mathrm{L}_{b}$ & Schumm (1956) \\
\hline 20. & Shape index $\left(S_{\mathrm{w}}\right)$ & $1 / F_{\mathrm{f}}$ & Horton (1932) \\
\hline 21. & Basin relief $(R)$ & $H-h$, Max Ele-Min ele & Schumm (1956) \\
\hline 22. & Relief ratio $\left(R_{\mathrm{r}}\right)$ & $R / \mathrm{L}_{b}$ & Schumm (1956) \\
\hline 23. & Ruggedness number $(\mathrm{Rn}) R * D_{\mathrm{d}}$ & & Strahler (1958) \\
\hline 24. & Dissection index $\left(D_{\mathrm{i}}\right)$ & $(H-h) / H$ & Singh and Dubey (1994) \\
\hline 25. & Gradient ratio $\left(R_{\mathrm{g}}\right)$ & $(H-h) / \mathrm{L}_{b}$ & Sreedevi et al. (2004) \\
\hline 26. & Melton ruggedness ratio $\left(M_{\mathrm{rn}}\right)$ & $(H-h) / A^{0.5}$ & Melton (1965) \\
\hline 27. & Texture ratio $\left(R_{\mathrm{t}}\right)$ & $\mathrm{N} 1 / P, \mathrm{~N} 1$ is number of first-order streams & Schumn (1965) \\
\hline 28. & Drainage intensity $\left(D_{\mathrm{i}}\right)$ & $F_{s} / D_{\mathrm{d}}$ & Faniran (1968) \\
\hline 29. & infiltration number $\left(I_{\mathrm{f}}\right)$ & $F_{s}^{*} D_{\mathrm{d}}$ & Faniran (1968) \\
\hline 30. & Lemniscate's $(k)$ & $\mathrm{L}_{b} 2 / 4 A$ & Chorley et al. (1957) \\
\hline 31. & Compactness coefficient $\left(C_{c}\right)$ & $0.2841 \mathrm{P} / A^{0.5}$ & Gravelius (1914) \\
\hline 32. & Slope analysis & GIS analysis/DEM & \\
\hline
\end{tabular}

\section{Drainage density $\left(D_{\mathrm{d}}\right)$}

Drainage density reflects the spacing of the drainage ways and interaction between geology and climate. Drainage density for the main watershed is calculated as $3.52 \mathrm{~km} / \mathrm{km}^{2}$ (Table 4). The density for the sub-basins indicates the terrain is an impervious and highly dissected one (Fig. 4). This low value of drainage density is an indication of resistant surface material and widely spread streams.

\section{Stream frequency $\left(F_{s}\right)$}

The stream frequency of Burma Nala basin is 9.63 (Table 4). In the sub-basin, the frequency varies from 5 to 13.04 (Table 5). The stream frequency exhibits a positive correlation with drainage density values in the study area (Fig. 5). 
Table 2 Linear aspects of Burma Nala watershed

\begin{tabular}{|c|c|c|}
\hline \multicolumn{2}{|l|}{ Parameter } & \multirow{2}{*}{$\begin{array}{l}\text { Dendritic } \\
18.51\end{array}$} \\
\hline Perimeter, $P$ & & \\
\hline Basin length, $\mathrm{L}_{b}$ & & 5.2 \\
\hline \multirow[t]{5}{*}{ No. of streams } & N1 & 57 \\
\hline & $\mathrm{N} 2$ & 12 \\
\hline & N3 & 4 \\
\hline & $\mathrm{N} 4$ & 1 \\
\hline & $\mathrm{Nt}$ & 74 \\
\hline \multirow[t]{4}{*}{ Mean stream length, $L_{\mathrm{um}}$} & L1 & 0.42 \\
\hline & L2 & 0.65 \\
\hline & L3 & 1.87 \\
\hline & L4 & 1.73 \\
\hline \multirow[t]{5}{*}{ Total stream length, $L_{\mathrm{u}}$} & LT1 & 24.2 \\
\hline & LT2 & 7.86 \\
\hline & LT3 & 7.49 \\
\hline & LT4 & 1.73 \\
\hline & LT & 41.28 \\
\hline \multirow[t]{4}{*}{ Bifurcation ratio, $R_{\mathrm{b}}$} & $R_{\mathrm{b}} 1 / 2$ & 4.75 \\
\hline & $R_{\mathrm{b}} 2 / 3$ & 3 \\
\hline & $R_{\mathrm{b}} 3 / 4$ & 4 \\
\hline & $R_{\mathrm{b}}$ & 3.92 \\
\hline \multirow[t]{5}{*}{ Stream length ratio, $R_{1}$} & $R_{1} 2 / 1$ & 0.32 \\
\hline & $R_{1} 3 / 2$ & 0.95 \\
\hline & $R_{1} 4 / 3$ & 0.23 \\
\hline & $R_{\mathrm{l}}$ & 0.5 \\
\hline & Rho & 0.13 \\
\hline
\end{tabular}

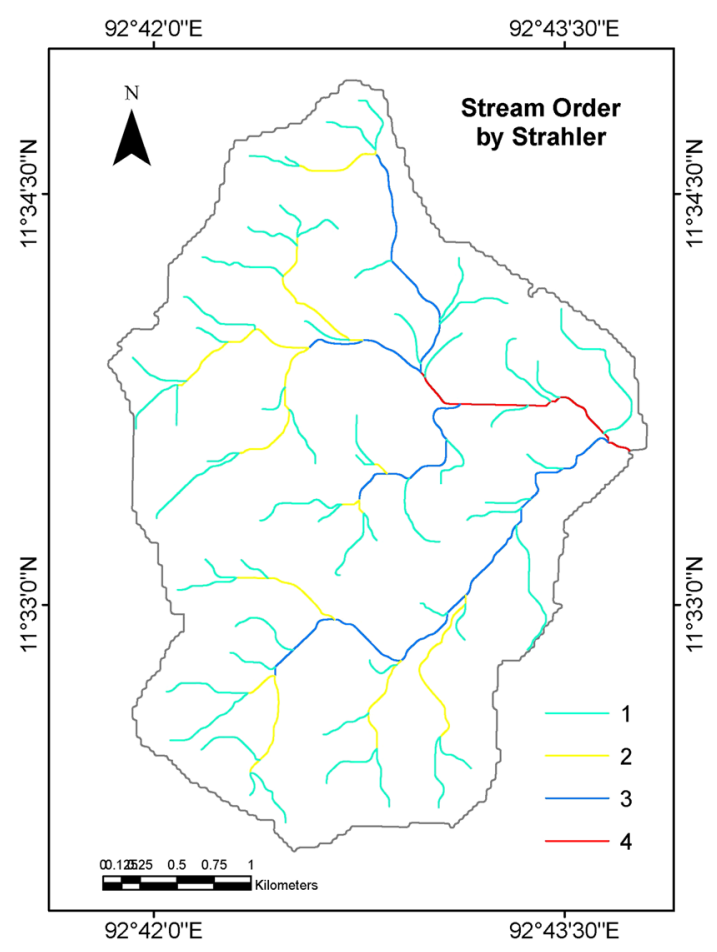

Fig. 3 Stream order of Burma Nala

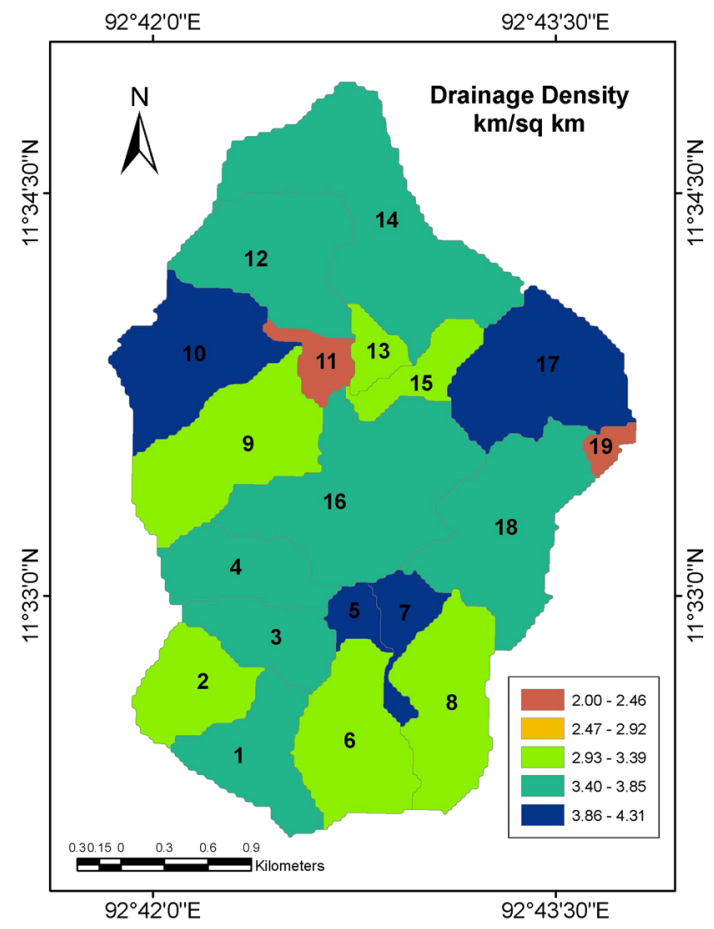

Fig. 4 Drainage density of Burma Nala watershed

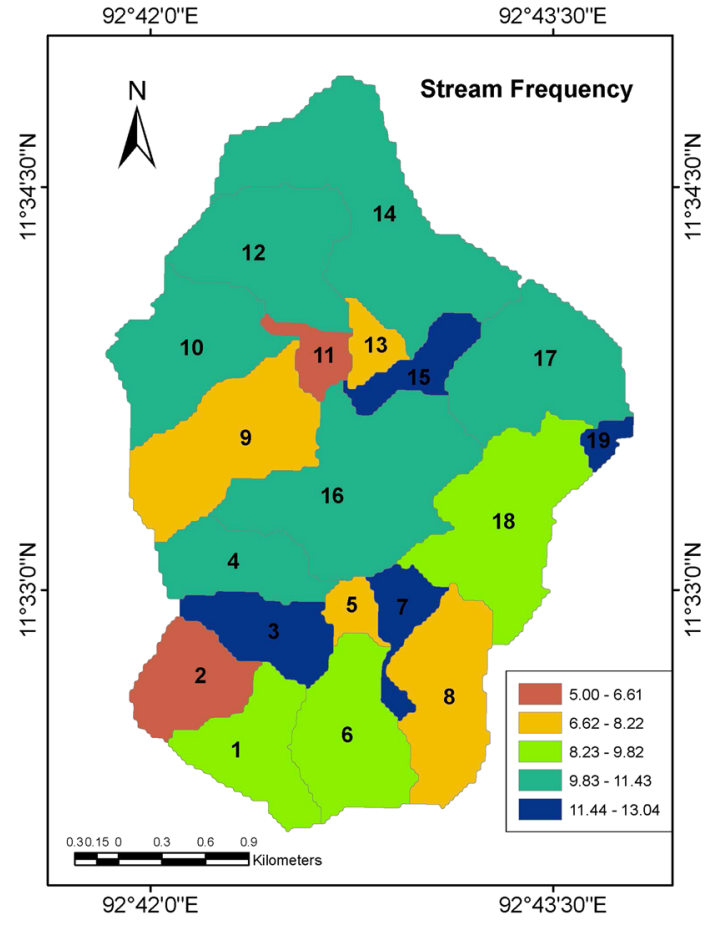

Fig. 5 Stream frequency of Burma Nala watershed 


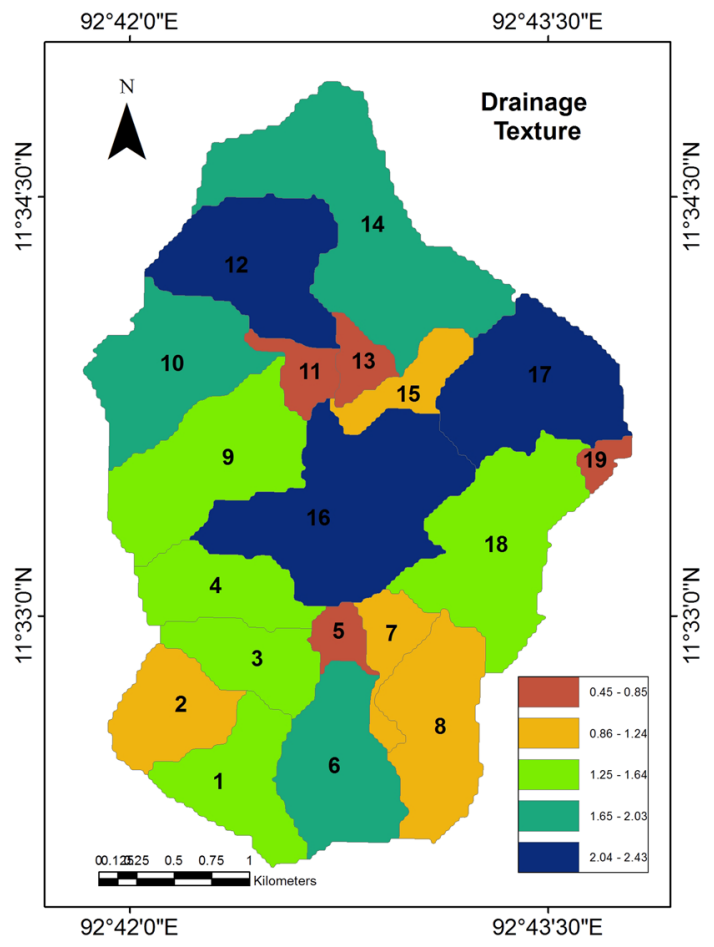

Fig. 6 Drainage texture of Burma Nala watershed

\section{Drainage texture $(t)$}

The density factor is also related to a parameter known as texture. The texture value calculated for the sub-basins varies between 0.45 in Basin ID 11 and 2.43 in Basin ID 16 (Table 5). In general, a region with a coarse texture has a mean value less than 4 , medium texture $4-10$ and fine texture greater than 10 . Thus, the present study area has very coarse to coarse texture (Fig. 6).

From an equation derived by Jacob (1944), transmissibility which is the measure of the permeability of the terrain varies inversely with the square of the drainage density (Table 3). "Thus, as transmissibility increases, drainage density would decrease and vice-versa" (Carlston 1963).

Thus, the law of high infiltration, low density and low infiltration high drainage density is implied in the study area.

\section{Length of overland flow $\left(L_{g}\right)$}

$L g$ value for the entire basin area is 0.14 (Table 4), which is quite low. The length of the overland flow varies within
Table 4 Morphometric parameters of Burma Nala watershed

\begin{tabular}{lrllll}
\hline Parameters & Value & Parameters & Value & Parameters & Value \\
\hline$A$ & 11.73 & $R_{\mathrm{c}}$ & 0.43 & Mrn & 0.05 \\
$D_{\mathrm{d}}$ & 3.52 & $R_{\mathrm{e}}$ & 0.74 & $D$ In & 1.79261 \\
$F_{s}$ & 6.31 & $S_{\mathrm{w}}$ & 2.32 & $I_{\mathrm{f}}$ & 22.2112 \\
$T$ & 3.99 & $R$ & 192 & $K$ & 0.22 \\
$L_{\mathrm{g}}$ & 0.14 & $R_{\mathrm{r}}$ & 0.04 & $C_{c}$ & 1.54 \\
$C$ & 0.28 & $\mathrm{Rn}$ & 0.67 & - & - \\
$F_{\mathrm{f}}$ & 0.43 & $D_{\mathrm{i}}$ & 0.99 & - & - \\
\hline
\end{tabular}

the sub-basins. It ranges from 0.12 to $0.25 \mathrm{~km}$ (Table 5). The minimum value of $L_{\mathrm{g}}$ indicates the surface runoff of the basin is low but in case of Basin IDs 2, 6, 9, 11, 13, 15, 17, it is relatively higher.

\section{Constant of channel maintenance $\left(C_{c}\right)$}

As stated by Schumn, drainage network develops in an orderly way since meter-by-meter growth of a drainage system is only possible if sufficient area is available to maintain the expanding channels. The $C_{c}$ value for the Burma Nala watershed is 0.28 (Table 4). Low value of $C_{c}$ indicates high drainage density, and thus less area is required to sustain $1 \mathrm{~km}$ channel. Here, the $C_{c}$ value 0.28 indicates $0.28 \mathrm{Km}^{2}$ basin area is needed to sustain a channel of $1 \mathrm{~km}$. In the subbasins, $C_{c}$ value varies between $0.23 \mathrm{KM}^{2}$ (Basin 5) and 0.5 $\mathrm{Km}^{2}$ (Basin 19) (Table 5).

\section{Form factor $\left(F_{f}\right)$}

The form factor value for the Burma Nala watershed is 0.43 (Table 4 ) which is a less elongated basin. The $F_{\mathrm{f}}$ value for the sub-basins varies from 0.03 to 1.01 (Table 5). The low $F_{\mathrm{f}}$ value indicates elongated basin which will have a flatter peak of flow for long duration.

\section{Elongation ratio $\left(R_{\mathrm{e}}\right)$}

The Burma Nala watershed is less elongated (0.7-0.8), i.e., the $R_{\mathrm{e}}$ value is 0.74 (Table 4 ). And among the sub-watersheds (Table 5), Basins 1, 2, 3, 5, 6, 14, 15, 16, 18 are less elongated (value ranges between 0.70 and 0.80 ) and basins $9,10,11,12,13,14$ are elongated (value less than 0.5 ) in nature (Fig. 7).

Table 3 Transmissibility was calculated for the study area which shows a sharp negative relation with $D_{\mathrm{d}}$

\begin{tabular}{lllllllllllllllllllll}
\hline Basin ID & 1 & 2 & 3 & 4 & 5 & 6 & 7 & 8 & 9 & 10 & 11 & 12 & 13 & 14 & 15 & 16 & 17 & 18 & 19 \\
\hline$D_{\mathrm{d}}$ & 3.39 & 3.19 & 3.6 & 3.6 & 4.31 & 3.13 & 3.96 & 3.27 & 2.97 & 3.85 & 2.05 & 3.73 & 3.2 & 3.65 & 3.12 & 3.6 & 4.14 & 3.6 & 2 \\
Transmissibility & 0.09 & 0.1 & 0.08 & 0.08 & 0.05 & 0.1 & 0.06 & 0.09 & 0.11 & 0.07 & 0.24 & 0.07 & 0.1 & 0.07 & 0.7 & 0.08 & 0.06 & 0.08 & 0.25 \\
\hline
\end{tabular}




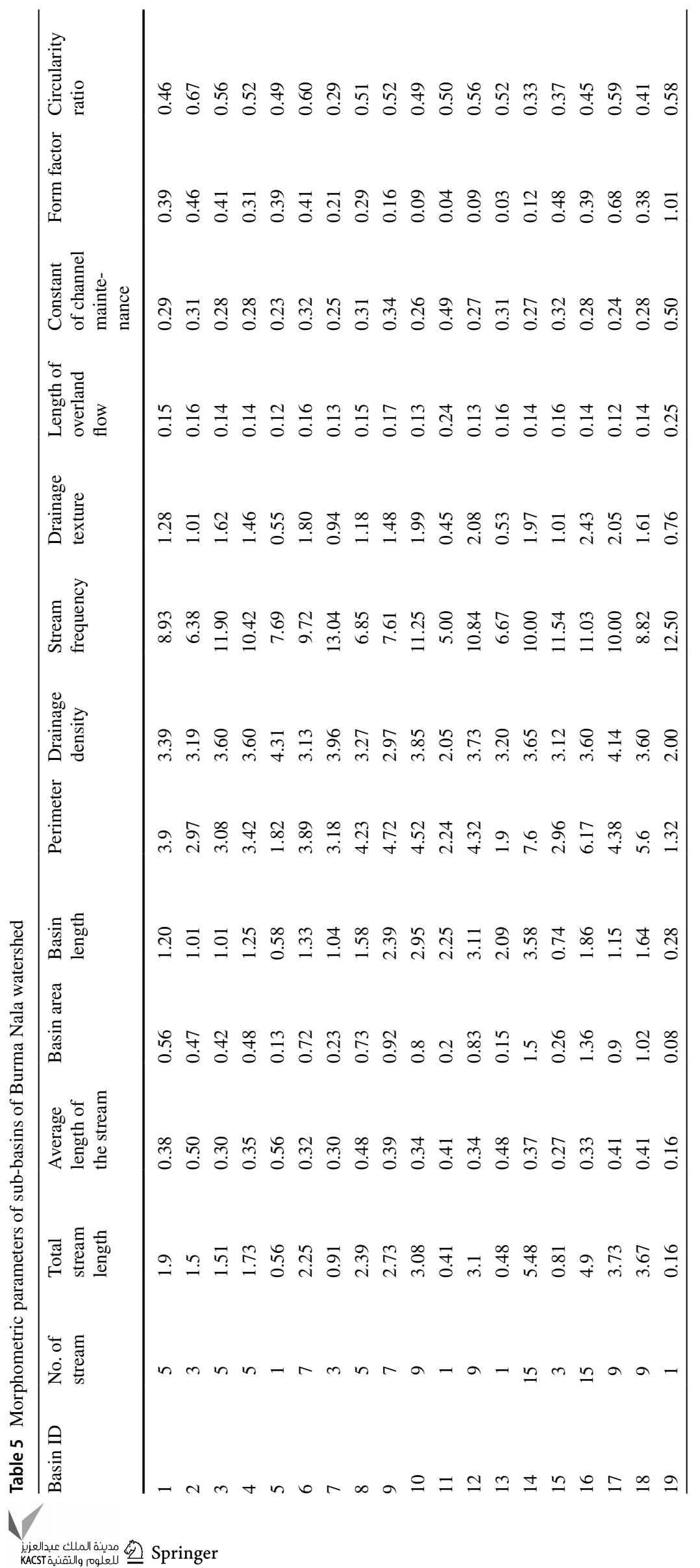




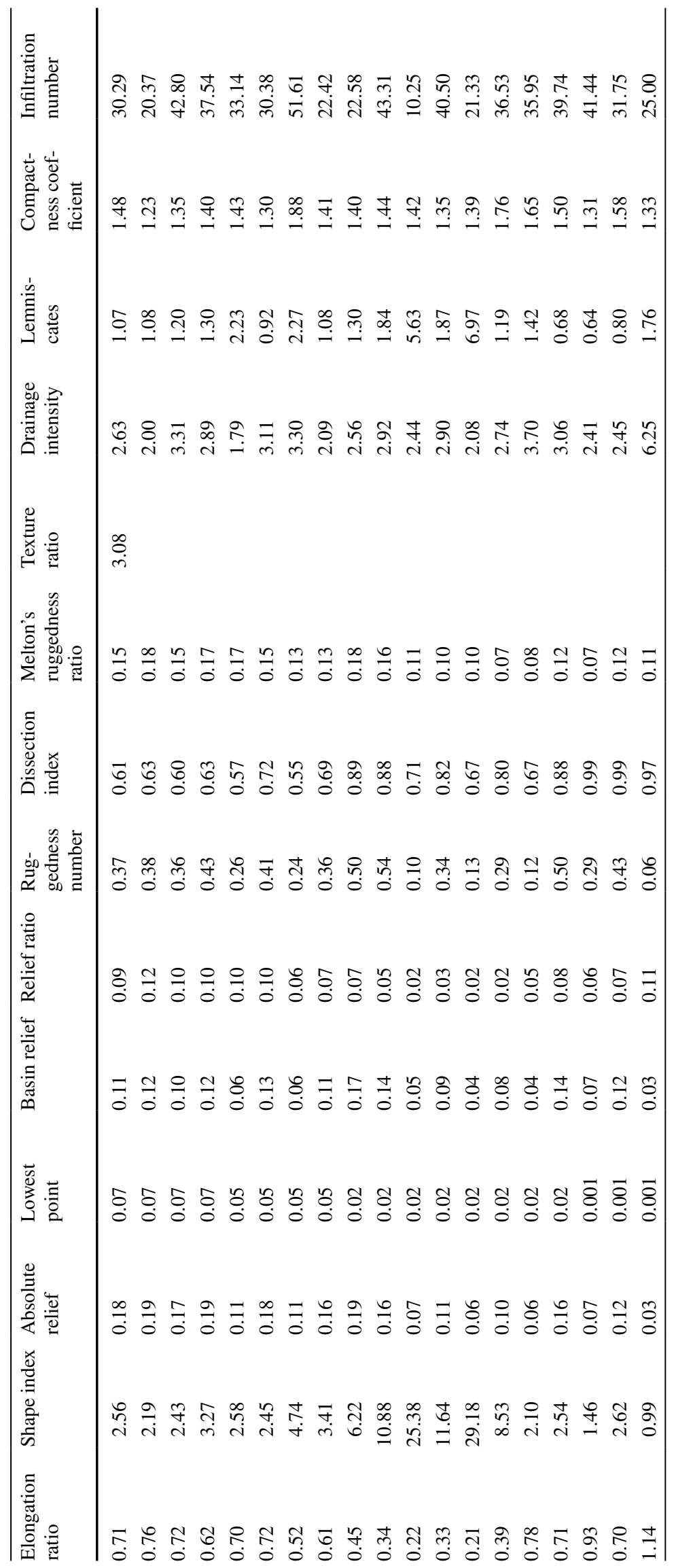




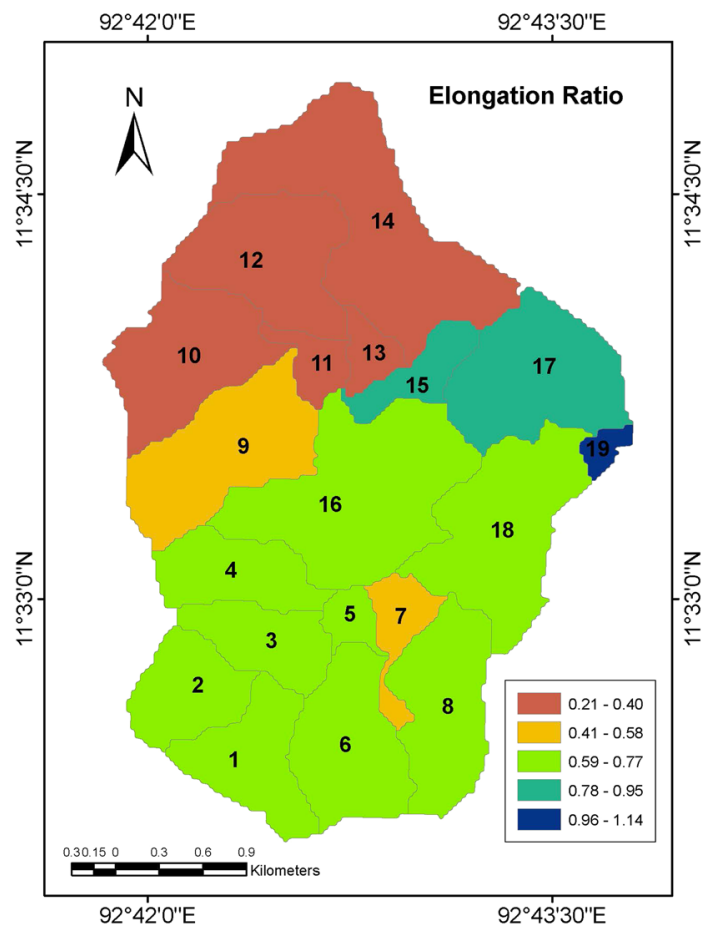

Fig. 7 Elongation ratio of Burma Nala watershed

\section{Circularity ratio $\left(R_{\mathrm{c}}\right)$}

The $R_{\mathrm{c}}$ value can attain a maximum of 1.0 where the outline of the watershed is approaching near-circularity. The $R_{\mathrm{c}}$ of the watershed is 0.43 (Table 4) which indicates elongated shape (Fig. 8). In the sub-basins, it varies from 0.29 (Basin 7) to 0.67 (Basin 2) (Table 5).

\section{Shape index $\left(S_{w}\right)$}

The $S_{\mathrm{w}}$ of the watershed is 2.32 (Table 4), and the subbasins are mainly within the range of 0.99-4.74 (Table 5). Although there are exceptions in Basins 10, 11, 12, 13, 14, their corresponding $S_{\mathrm{w}}$ values are 10.88, 25.38, 11.64, 29.18 and 8.53 (Fig. 9).

\section{Relief aspects}

\section{Basin relief $(R)$}

Basin relief (Fig. 10) is a parameter that determines the stream gradient and the volume of sediment that can be transported (Hadley and Schumm 1961). The relief of the Burma Nala watershed is $192 \mathrm{~m}$ (Table 4), and in the subbasin, it varies largely from 30 to $170 \mathrm{~m}$ (Table 5).

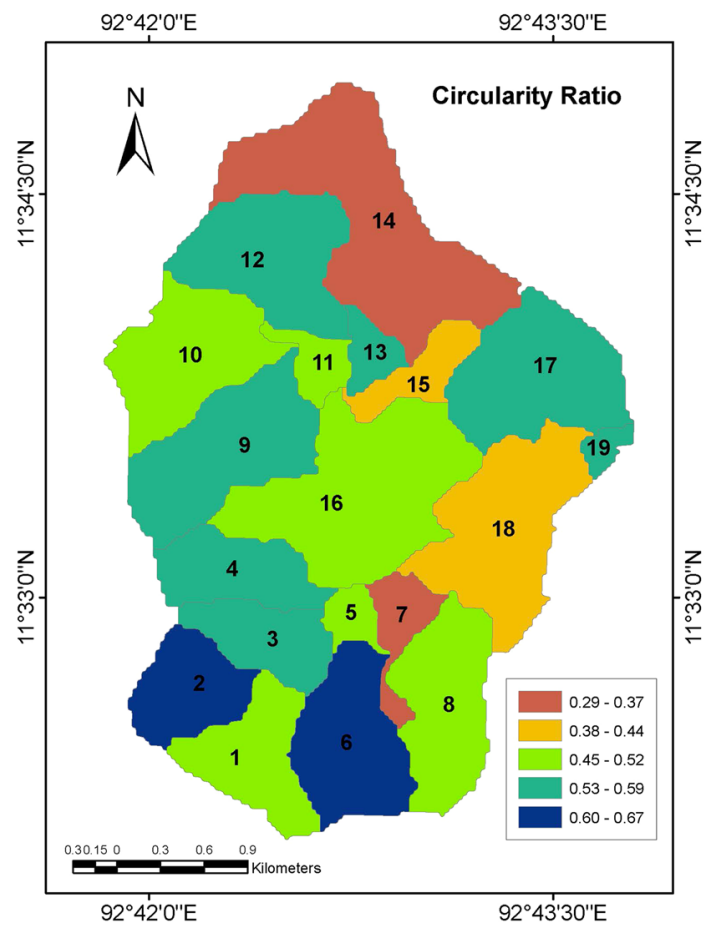

Fig. 8 Circularity ratio of Burma Nala watershed

\section{Relief ratio $\left(R_{\mathrm{r}}\right)$}

The $R_{\mathrm{r}}$ value for the Burma Nala watershed is 0.04 (Table 4). In the sub-basins, the $R_{\mathrm{r}}$ was calculated (Table 5) and found to be low, ranging from 0.02 to 0.12 . This value of $R_{\mathrm{r}}$ is mainly due to resistant sandstone underlying the basin and low degree of slope.

\section{Ruggedness number (Rn)}

The value of $\mathrm{Rn}$ for the watershed is 0.67 (Table 4), and for the sub-basins 4, 6, 9, 10, 16, 18, $\mathrm{Rn}$ is relatively higher (Fig. 11) and the corresponding values are 0.43, 0.41, 0.50, $0.54,0.50$ and 0.43 , respectively (Table 5). As per Strahler's (1956) observation, $\mathrm{Rn}$ increases directly with the drainage density and relative relief of the area fits into this drainage basin also. When drainage density increases, the relative height remains constant. The average horizontal distance from divide to adjacent channels is reduced with an increase in slope steepness. On the other hand, when the relative height increases, the drainage density remains constant. The elevation difference between divides and adjacent channel will also increase, and thus the slope steepness also increases. 


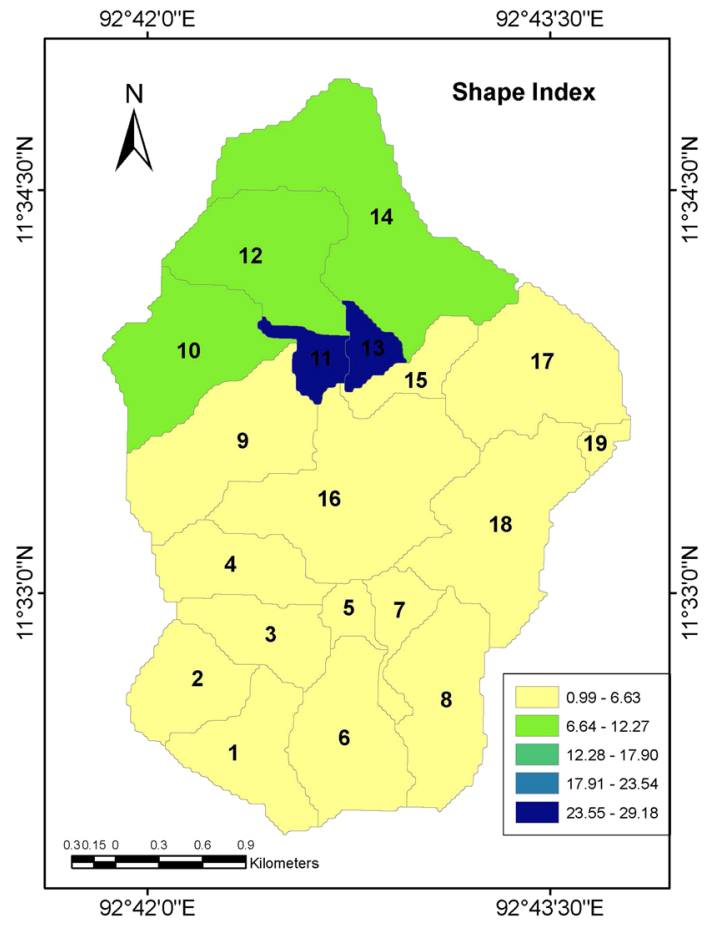

Fig. 9 Shape index of Burma Nala watershed

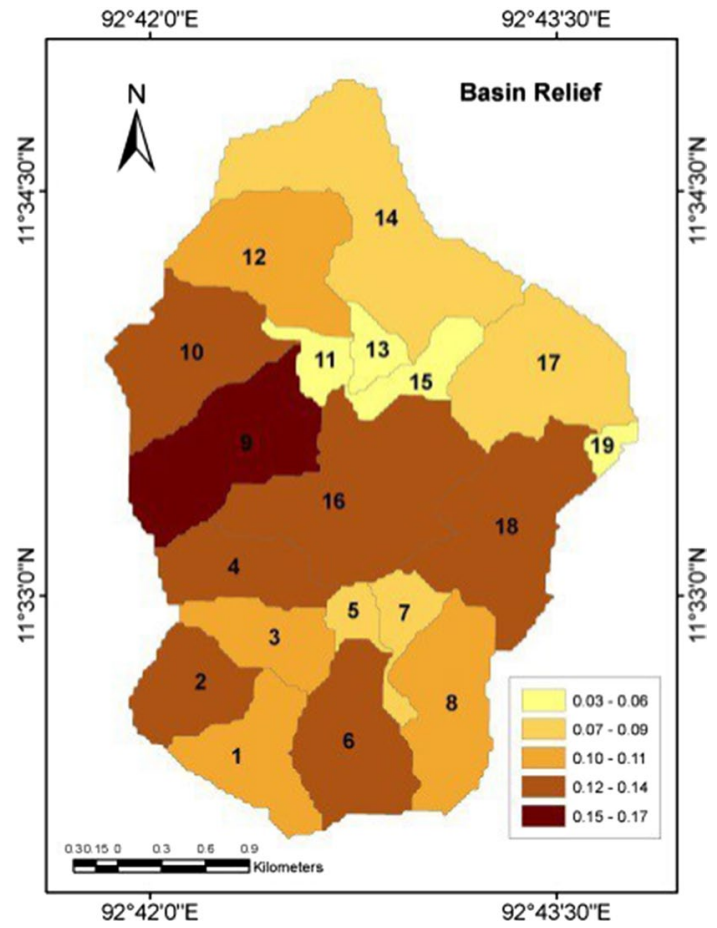

Fig. 10 Basin relief of Burma Nala watershed

\section{Dissection index $\left(D_{i}\right)$}

Dissection index for the Burma Nala watershed was calculated as 0.99 (Table 4). The index of the sub-basins varies

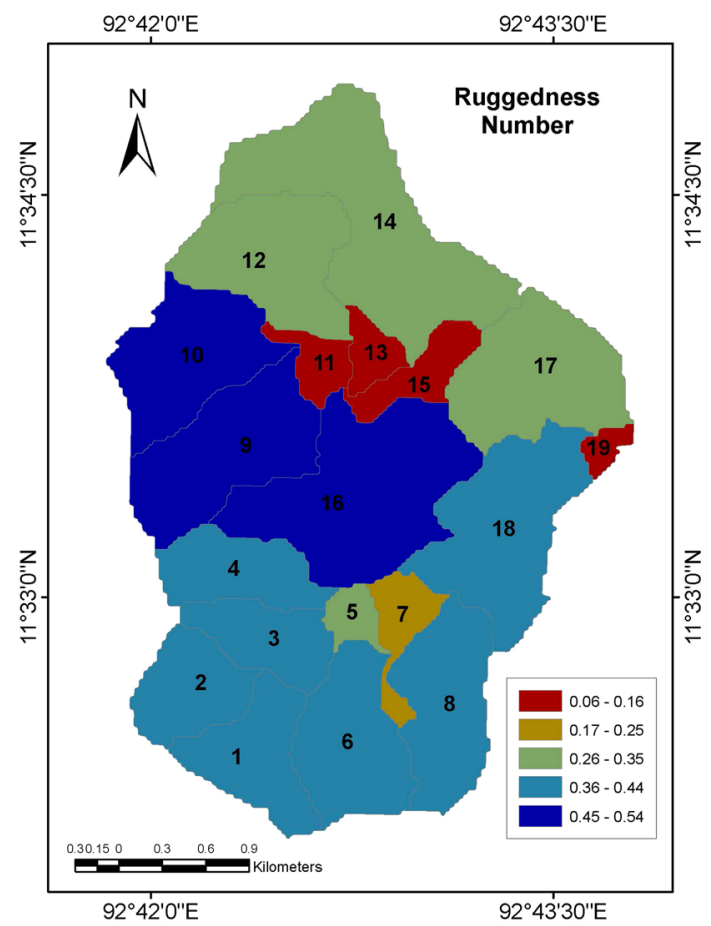

Fig. 11 Ruggedness number of Burma Nala watershed

from 0.55 (Basin 7) to 0.99 (Basin 17, 18). The maximum $D_{i}$ value for the basin and sub-basins $(6,9,10,11,12,14$, $16,17,18$ and 19) (Table 5) implies that the watershed is a highly dissected (Fig. 12) one with vertical escarpment and hill slope.

\section{Melton ruggedness number (mrn)}

Melton ruggedness number is used to identify the hydrogeomorphic process which is dominant in a particular watershed. Generally, Melton ratio less than 0.30 is the characteristic of water flood. Values ranging from 0.30 to 0.6 are debris flood and greater than 0.6 represent debris flow. Though the Melton ratio is higher (0.05) (Table 4) for the entire watershed, the ratio for the sub-watersheds varies from 0.07 to 0.18 (Table 5) which is waterflood-prone basin.

\section{Texture ratio $\left(R_{t}\right)$}

Texture ratio depends on the underlying lithology, infiltration capacity and the relief aspect of the terrain. The texture ratio for the watershed is 3.08 (Table 5) which is categorized as moderate in nature.

\section{Drainage intensity $\left(D_{i}\right)$}

The watershed value is 1.79 (Table 4) which indicates a lower range. The drainage density value implies that 


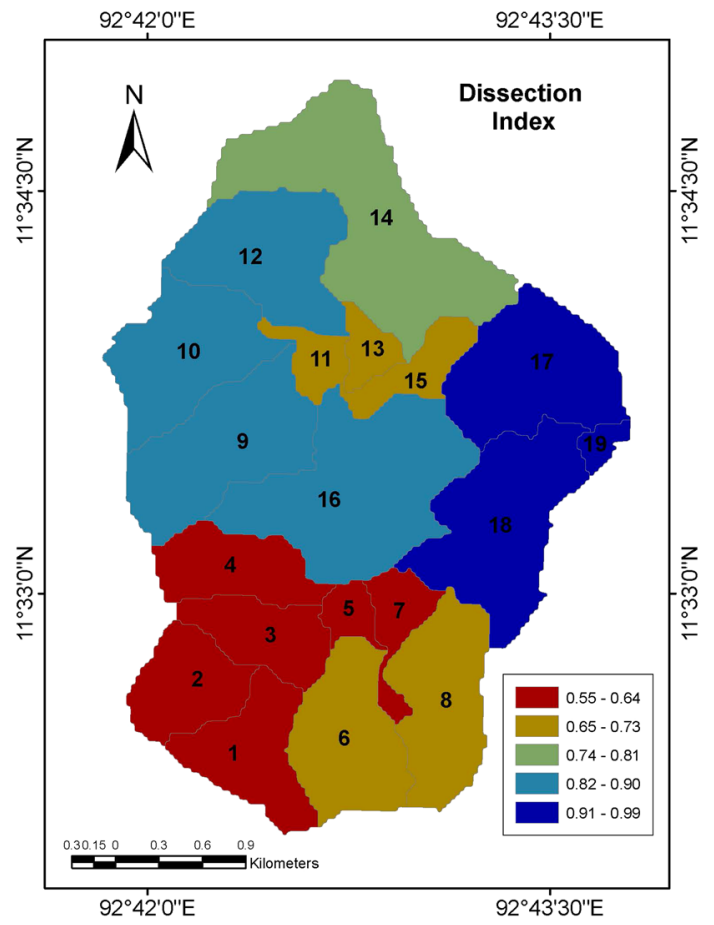

Fig. 12 Dissection index of Burma Nala watershed

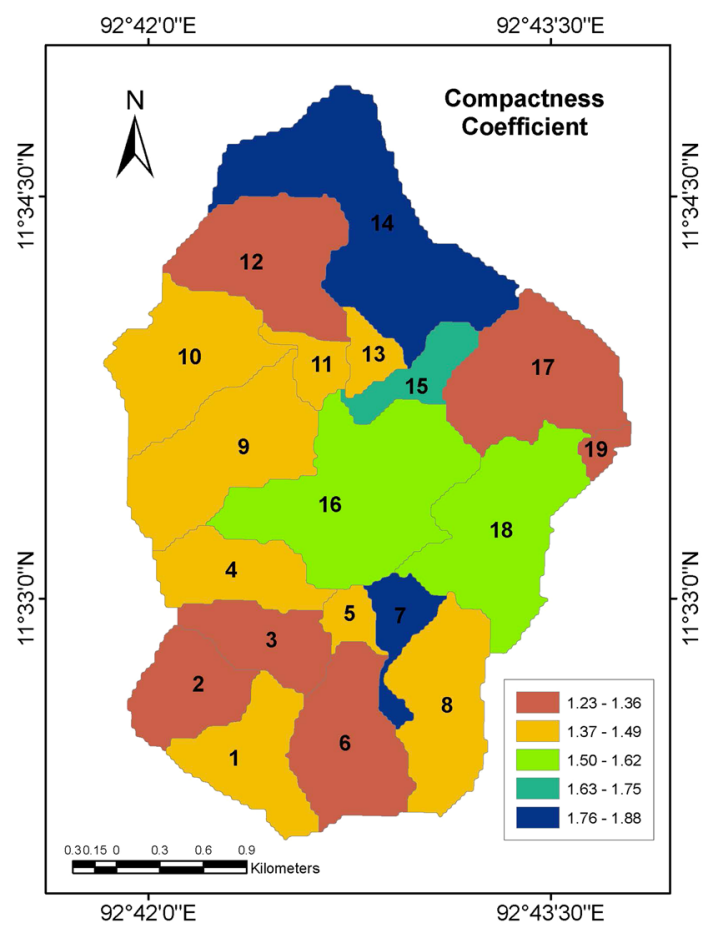

Fig. 13 Compactness coefficient of Burma Nala watershed

drainage density and stream frequency have little effect on the extent to which the surface has been covered by agents of denudation.
Infiltration number $\left(I_{\mathrm{f}}\right)$

The infiltration of Burma Nala waterfall is 22.2 (Table 4). $I_{\mathrm{f}}$ for the sub-watersheds varies from 10.25 to 51.61 (Table 5). The higher value of infiltration number indicates that the infiltration capacity is very low due to impermeable surface material, resulting into high runoff.

\section{Lemniscate's $(k)$}

Chorley et al. (1957) expressed another parameter named lemniscate's value to determine the slope of the basin. The lemniscate's value for Burma Nala basin is 0.22 (Table 4).

\section{Compactness coefficient $\left(C_{c}\right)$}

The value varies from 1.23 (Basin 2) to 1.88 (Basin 7) (Table 5) (Fig. 13).

The statistical analysis of interrelationships of morphometric parameters (Table 6) helps in understanding the terrain characteristics of watershed management and planning. From the Pearson's correlation matrix for Burma Nala watershed (Table 6), total length of the stream $\left(L_{u}\right)$ is positively correlated with the area $(A)(0.98)$. Mean stream length $\left(L_{\mathrm{sm}}\right)$ is positively correlated with stream frequency $\left(F_{\mathrm{s}}\right)(0.11)$ though the relationship is insignificant. Drainage density $\left(D_{\mathrm{d}}\right)$ is negatively correlated with the length of overland flow $\left(L_{\mathrm{g}}\right)(-0.969)$ and negatively correlated with constant of channel maintenance $(C)$ $(-0.971)$. The length of overland flow has a significant positive correlation with constant of channel maintenance $(C)(0.995)$.

The pairwise relationship of different morphometric parameters of Burma Nala watershed (Table 7) reveals that there is a significant relationship between total number of streams and total stream length with a coefficient determining the prediction equation being 0.962 which implies that $96 \%$ of the variation in total stream length is explained by the linear relationship between total number of streams and total stream length (as described by the regression equation). The other $4 \%$ of the total variation in total stream length remains unexplained. Similarly, $93 \%$ of the total variation in basin area is explained by the total number of streams (0.939), whereas $89 \%$ of the total variation in perimeter is explained by the total number of streams (0.899). Seven percent of variation of drainage density is explained by stream frequency (0.071), 94\% of variation of drainage density is explained by length of overland flow (0.940) and 94\% is explained by constant of channel maintenance (0.944).

\section{Hypsometric analysis}

Hypsometric curve and hypsometric integral properties of any hydraulic basin are an important morphometric 
Table 6 Correlation matrix

\begin{tabular}{llllllllll}
\hline & $A$ & $P$ & $\mathrm{Lu}$ & $\mathrm{Lsm}$ & $D_{\mathrm{d}}$ & $F_{s}$ & $\mathrm{LoF}$ & $C_{c}$ & $\mathrm{Nu}$ \\
\hline$A$ & 1 & & & & & & & \\
$P$ & 0.973185 & 1 & & & & & & & \\
$L_{\mathrm{u}}$ & 0.988961 & 0.964409 & 1 & & & & & & \\
$\mathrm{Lsm}$ & 0.888853 & 0.828947 & 0.912993 & 1 & & & & & \\
$D_{\mathrm{d}}$ & 0.327995 & 0.370029 & 0.418871 & 0.55327 & 1 & & & & \\
$F_{s}$ & 0.087206 & 0.137409 & 0.150315 & 0.118254 & 0.266801 & 1 & & & \\
$\mathrm{LoF}$ & -0.40514 & -0.45048 & -0.47538 & -0.62575 & -0.96961 & -0.22264 & 1 & & \\
$C_{c}$ & -0.38175 & -0.43242 & -0.45261 & -0.59134 & -0.97143 & -0.22103 & 0.995819 & 1 & \\
$\mathrm{Nu}$ & 0.969513 & 0.948069 & 0.980711 & 0.87754 & 0.394823 & 0.277102 & -0.44993 & -0.42725 & 1 \\
\hline
\end{tabular}

Table 7 Coefficient of linear regression between morphometric parameters

\begin{tabular}{llll}
\hline Relationship between & Linear regression equation & $\begin{array}{l}\text { Coefficient of determi- } \\
\text { nants }\left(R^{2}\right)\end{array}$ & $\begin{array}{c}\text { Correlation } \\
\text { coefficient }(R)\end{array}$ \\
\hline Total number of streams and total stream length & $Y=2.7423 x-0.0134$ & 0.962 & 0.981 \\
Total number of streams and Basin area & $Y=10.107 x-0.3082$ & 0.939 & 0.969 \\
Total number of streams and Perimeter & $Y=2.59993 x-3.9327$ & 0.899 & 0.948 \\
Stream frequency and drainage density & $Y=1.0122 x+6.055$ & 0.071 & 0.267 \\
Length of overland flow and drainage density & $Y=-0.0568 x+0.3465$ & 0.940 & 0.969 \\
Constant of channel maintenance and drainage density & $Y=-0.1174 x+0.7044$ & 0.944 & 0.971 \\
\hline
\end{tabular}

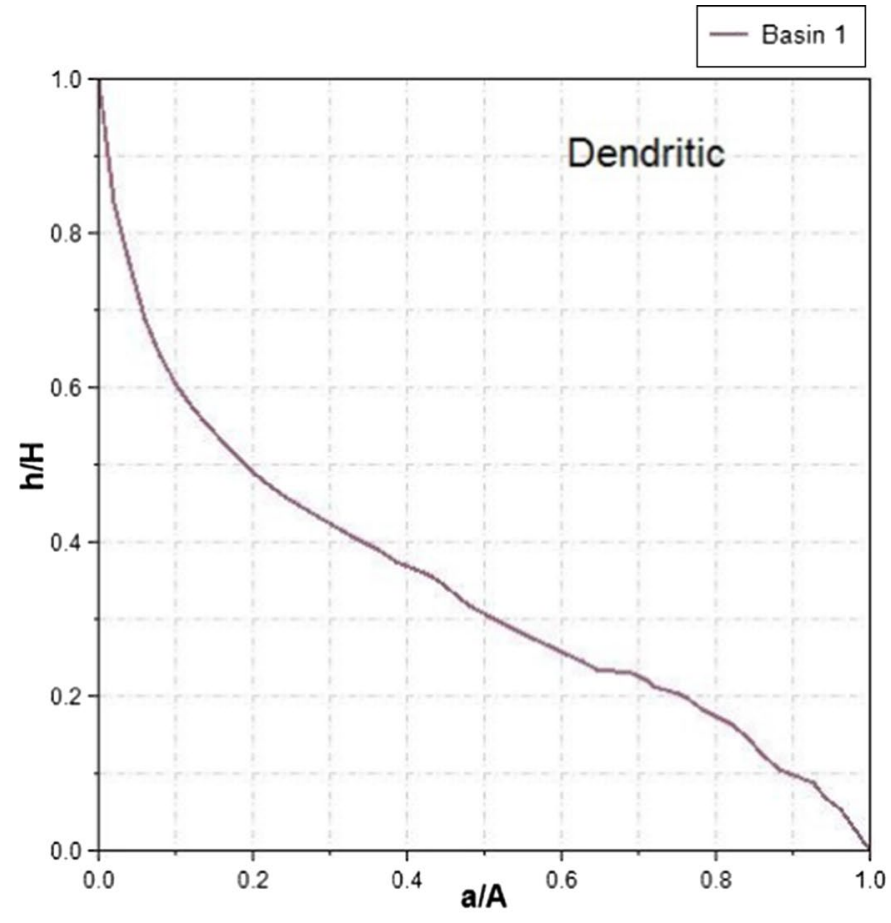

(a)

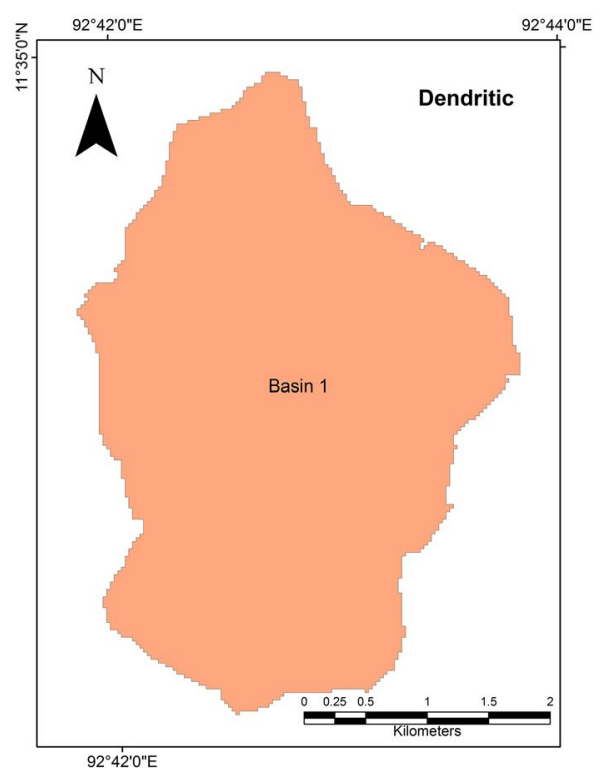

(b)

Fig. 14 a Percentage hypsometric curve, $b$ the basin

parameter in order to investigate erosional stage of basin. The hypsometric curve of a basin or watershed represents the relative area of the watershed below or above a given altitude (Strahler 1952). It describes the distribution of elevation across the area. The curve is derived by plotting the proportion of total basin height against the proportion of 


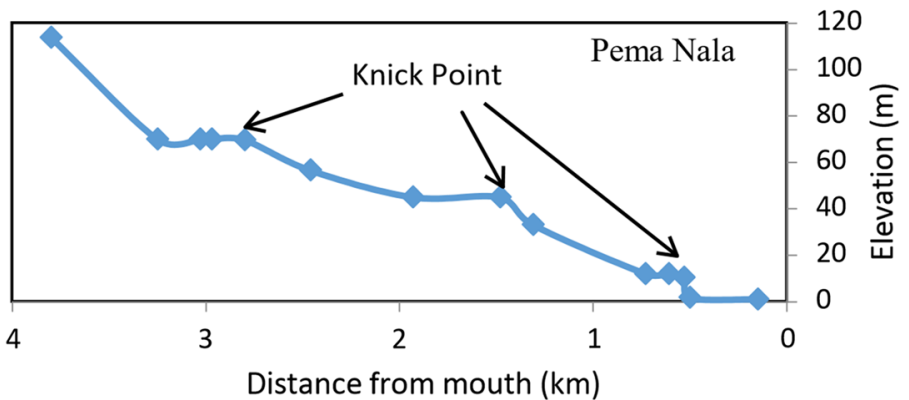

(a)

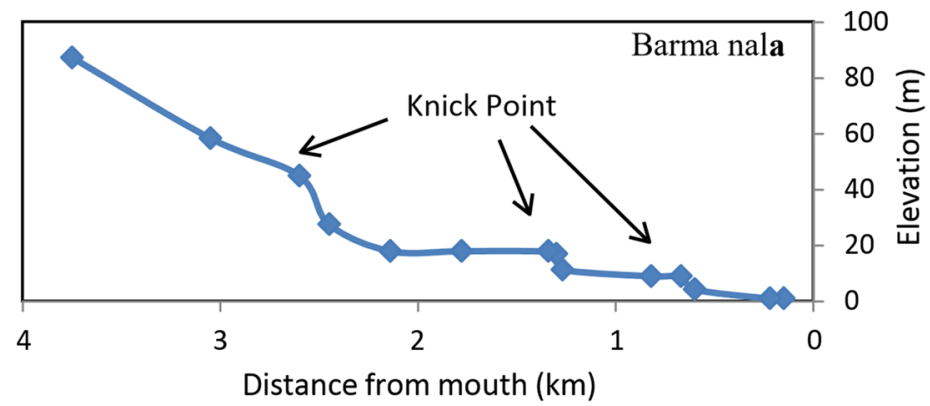

100

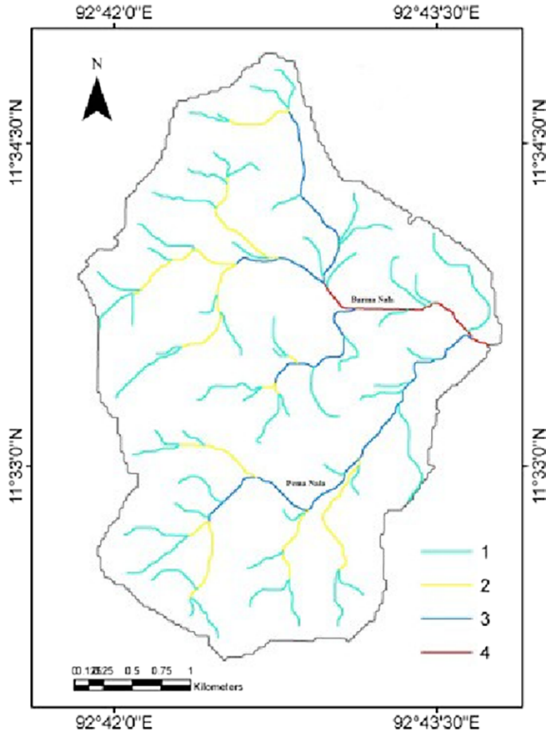

(c)

(b)

Fig. 15 Longitudinal profile: a Pema Nala, b Burma Nala, c location of Burma Nala and Pema Nala

total basin area. The area below the hypsometric curve is known as the hypsometric integral (HI) which varies from 0 to 1 . A low hypsometric integral value suggests an old, eroded, evenly dissected drainage basin and thus represents concave curve, whereas the high values of hypsometric integral indicate that most of the topography is less eroded and highly relative to the mean elevation. This is applicable to young uplifted ranges cut by deeply incised streams, hence representing convex curve.

In this study, the hypsometric curve (Fig. 14a) and hypsometric integral analysis are applied on the watershed area. According to the generated result, the hypsometric integral value of the Burma Nala watershed is 0.34 . The lower value indicates that it is denuded, matured and relatively stable basin. The curve area shows that the basin area (or volume of rock and soil) resides at relatively low elevation. The materials have been removed from higher areas and transported to lower areas.

Hypsometric Integral = (Mean Elevation - Minimum elevation $) /$

(Maximum Elevation - Minimum Elevation)

$=(65.5998-1) /(193-1)=0.34$

\section{River's long profile}

The long profile of a river shows how the gradient of the river changes from its source to mouth. A stream channel in a condition of equilibrium can attain steady-state condition and has a distinct longitudinal profile (Mackin 1948). Any peculiarities in the longitudinal profile like Knickpoints and knick zones indicate a disturbance in the steady-state condition of the channel (Siedl and Dietrich 1992; Hayakawa and Matsukura 2003; Wobus et al. 2006). Longitudinal profile of Burma Nala and Pema Nala has been computed (Fig. 15) below. Within a reach of $4 \mathrm{~km}$, three major Knickpoints were identified from outlets to headwaters along the longitudinal profile of each stream. The Knickpoints of Burma Nala are at $12 \mathrm{~m}, 20 \mathrm{~m}$ and $48 \mathrm{~m}$ elevation and $500 \mathrm{~m}, 1.3 \mathrm{~km}$ and $2.6 \mathrm{~km}$ from the mouth, respectively. And for Pema Nala, they are at $10 \mathrm{~m}, 48 \mathrm{~m}$ and $68 \mathrm{~m}$ elevation and $500 \mathrm{~m}, 1.5 \mathrm{~km}$ and $3 \mathrm{~km}$ from the mouth, respectively.

\section{Conclusion}

The analysis performed for the Burma Nala river basin of South Andaman Island provides information regarding the hydrogeologic condition of the basin.

1. A high proportion of the first-order stream $(77.02 \%$ maximum proportion) denotes the presence of structural breaks like lineaments, fractures, etc.

2. The drainage density indicates impermeable terrain and highly dissected with coarse drainage texture.

3. The relief aspects show that the watershed is structurally complex mountainous landscape. 
4. The channels are short flowing having small hinterland and thus do not carry much sediment with them. Within a short length of $4 \mathrm{~km}$, three Knickpoints are found. The three Knickpoints on each of the two different channels located at the same elevation explain clearly the influence of three phases of tectonic upliftment.

5. Hypsometric integral value of 0.34 indicates moderately old, eroded and evenly dissected drainage basin.

Thus, tectonic has a very well pronounced influence over the drainage of the island. The morphometric parameters evaluated using GIS helped to understand various terrain characteristics (like nature of bedrock, runoff, infiltration capacity, etc.), hydrological behavior of the island system and the tectonic influence over the development and evolution of the drainage network of a small island.

Acknowledgements Thanks are due to Abhijit Rana for his technical support, and without his assistance, it would not have been possible to accomplish this artifact. Authors also present gratitude to everyone who has been supportive in the preparation of this research paper.

Funding The authors received no specific funding for this work.

\section{Compliance with ethical standards}

Conflict of interest Authors declare that they have no conflict of interest in publishing the current paper.

Ethical approval The research is based on effective and efficient use of maps and satellite images. Therefore, this particular research does not require any ethical approval.

Open Access This article is distributed under the terms of the Creative Commons Attribution 4.0 International License (http://creativeco mmons.org/licenses/by/4.0/), which permits unrestricted use, distribution, and reproduction in any medium, provided you give appropriate credit to the original author(s) and the source, provide a link to the Creative Commons license, and indicate if changes were made.

\section{References}

Abrahams AD (1984) Channel networks: a geomorphological perspective. Water Resour Res 20:161-168

Agarwal CS (1998) Study of drainage pattern through aerial data in Naugarh area of Varanasi district, U.P. J Indian Soc Remote Sens 26:169-175

Biswas S, Sudhakar S, Desai VR (1999) Prioritisation of sub-watersheds based on morphometric analysis of drainage basin- a remote sensing and GIS approach. J Indian Soc Remote Sens 27:155-166

Carlston CW (1963) Drainage density and streamflow. US Geol Survey Prof Paper, 422-C, 1-8

Chorley RJ, Malm DEG, Pogorzelski HA (1957) A new standard for estimating drainage basin shape. Am J Sci 255:138-141

Curray JR, Moore DG, Lawver LA, Emmel FJ, Raitt RW, Henry M, Kieckhefer R (1979) Tectonics of the Andaman Sea and Barma. In: Watkins J, Montadert L, Dickerson PW (eds) Geological and geophysical investigations of continental margins American Association Petroleum Geologists, Memoir, vol 29, pp 189-198

Faniran A (1968) The index of drainage intensity-A provisional new drainage factor. Aust J Sci 31:328-330

Frissel CA et al (1986) A hierarchical framework for stream habitat classification-viewing streams in a watershed context. Environ Manag 10:199-214

Gravelius H (1914) Flusskunde. Goschen'sche Verlagshandlung, Berlin

Hadley RF, Schumm SA (1961) Sediment sources and drainage basin characteristics in upper Cheyenne River basin, USGS Water-Supply Paper, 1531-B, 137-197

Hajam RA, Hamid A, Dar NA, Bhat SU (2013) Morphometric analysis of vaishav drainage basin using geo- spatial technology (GST). Int Res J Geol Min (IRJGM) 3(3):136-146

Hayakawa Y, Matsukura Y (2003) Recession rates of waterfalls in Boso Peninsula, Japan, and a predictive equation. Earth Surf Proc Land 28:675-684

Horton RE (1932) Drainage basin characteristics. Trans Am Geophys Union 13:35061

Horton RE (1945) Erosional development of streams and their drainage basins: hydrophysical approach to quantitative morphology. Bull Geol Soc Am 56:275-370

Jacob CE (1944) Correlation of ground-water levels and precipitation on Long Island, part 2, correlation of data. Trans Am Geophys Union 25:928-939

Krishnamurthy J, Srinivas G (1995) "Role of geological and geo-morphological factors in groundwater exploration: a study using IRS LISS data. Int J Remote Sens 16:2595-2618

Leopold LB, Maddock Jr T (1953) The hydraulic geometry of stream channels and some physiographic implications. U.S. Geological Survey Professional Paper, vol 252, p 57

Lotspeich FB, Platts WS (1982) An integrated land-aquatic classification system. North Am J Fish Manag 2:138-149

Mackin JH (1948) Concept of the graded river. Geol Soc Am Bull 59:463-512

Melton MA (1965) The geomorphic and paleoclimatic significance of alluvial deposits in Southern Arizona. J Geol 73:1-38

Mesa LM (2006) Morphometric analysis of a subtropical Andean basin (Tucuman, Argentina). Environ Geol 50:1235-1242

Miller VC (1953) A quantitative geomorphic study of drainage basin characteristics in the Clinch mountain area, Virginia and Tennessee. Technical report 3. Columbia University, New York: Office of Naval Research, Department of Geology

Nag SK (1998) Morphometric analysis using remote sensing techniques in the Chaka sub- basin Purulia district, West Bengal. J Indian Soc Remote Sens 26:69-76

Nageswara Rao K, Swarna LP, Kumar AP, Hari KM (2010) Morphometric analysis of Gostani River basin in Andhra Pradesh state, India using spatial information technology. Int J Geom Geosci 1(2)

Pareta K, Pareta U (2011) Quantitative morphometric analysis of a watershed of Yamuna Basin India using ASTER (DEM) data and GIS. Int J Geom Geosci 2(1)

Schumm SA (1956) Evolution of drainage systems \& slopes in badlands at Perth Amboy, New Jersey. Bull Geol Soc Am 67:597-646

Schumm SA (1965) Quaternary palaeohydrology. In: Wright HE, Frey DG (eds) The quaternary of the United States, pp 783-794

Siedl MA, Dietrich WE (1992) The problem of channel erosion into bedrock. Catena Suppl 23:101-124

Singh S, Dubey A (1994) Geo environmental planning of watersheds in India. Chugh Publications, Allahabad, pp 28-69

Sreedevi PD, Subrahmanyam K, Ahmed S (2004) The significance of morphometric analysis for obtaining groundwater potential zones in a structurally controlled terrain. Environ Geol 47:412420 
Srivastava VK, Mitra D (1995) Study of drainage pattern of Raniganj Coalfield (Burdwan District) as observed on Landsat-TM/IRS LISS II imagery. J Indian Soc Remote Sens 23:225-235

Strahler AN (1952) Quantitative geomorphology of erosional landscapes. In: 19th international geological congress, Algiers, Section 33, pp 341-354

Strahler AN (1953) Hypsometric analysis of erosional topography. Bull Geol Soc Am 63:1117-1142

Strahler AN (1958) Dimensional analysis applied to fluvially eroded landforms. Geol Soc Am Bull 69:279-300

Strahler AN (1964) Quantitative geomorphology of drainage basin and channel networks. In: Chow VT (ed) Handbook of applied hydrology. McGraw Hill Book, New York, pp 4-76
Vittala SS, Govindaiah S, Honne GH (2004) Morphometric analysis of sub-watersheds in the Pawagada area of Tumkur district, South India, using remote sensing and GIS techniques. J Indian Soc Remote Sens 32(4):351-362

Wobus C, Whipple KX, Kirby E, Snyder N, Johnson J, Spyropolou K, Crosby B, Sheehan D (2006) Tectonics from topography: procedures, promise, and pitfalls. Geol Soc Am Spec Pap 398:55-74

Publisher's Note Springer Nature remains neutral with regard to jurisdictional claims in published maps and institutional affiliations. 